\title{
М.А. Демин
}

\section{ТЕРНИСТЫЙ ПУТЬ В НАУКУ}

\author{
Статья подготовлена при финансовой поддержке РФФИ, проект № 17-11-22005 \\ «Историк в региональном сочиокультурном пространстве второй половины ХХ в.».
}

\begin{abstract}
На основе неопубликованных архивных источников раскрываются перипетии, связанные с изданием монографий и защитой диссертационных работ известным сибирским историком и археологом Алексеем Павловичем Уманским. Анализируются его контакты с ведущими российскими гуманитариями-сибиреведами: А.П. Окладниковым, Л.П. Потаповым, В.Г. Мирзоевым, Л.Р. Кызласовым, Н.А. Миненко. В публикации затрагиваются вопросы, связанные с повседневной научн ой жизнью исследователя, впервые рассматривается его полемика с Л.П. Потаповым и анализируется анонимная рецензия на его монографию. Ключевые слова: Уманский; история; телеуты; рецензия; монография; диссертация.
\end{abstract}

Целью статьи является введение в научный оборот новых неопубликованных материалов, раскрывающих перипетии, связанные с изданием монографий и защитой диссертационных работ известным сибирским историком и археологом Алексеем Павловичем Уманским. После демобилизации с фронта и окончания экстерном исторического факультета Барнаульского педагогического института он трудился в этом же вузе, а затем в управлении культуры Алтайского крайисполкома старшим инспектором по музеям и охране памятников, целенаправленно занимался выявлением, обследованием и раскопками археологических объектов, опубликовал большую серию научно-популярных работ по археологической тематике $[1,2]$. В 1963 г. А.П. Уманский возвращается к преподавательской деятельности в Барнаульском пединституте, планируя поступить в годичную аспирантуру Ленинградского отделения Института археологии АН СССР. Однако почти три года ему пришлось потратить на преодоление различных бюрократических преград, и в итоге проблему с аспирантурой удалось решить только в ведомственных рамках Кемеровского педагогического института [3].

Научным руководителем соискателя был утвержден В.Г. Мирзоев, который незадолго до этого защитил докторскую диссертацию по историографии Сибири и не взялся руководить работой по незнакомой для него археологической проблематике. Тогда А.П. Уманский предложил тему по истории телеутов в XVII - первой четверти XVIII в., по которой он начал собирать материалы еще с середины 1950-х гг. В результате Уманскому пришлось круто изменить уже устоявшиеся планы научных работ и осваивать тематику, которая не предполагала использование годами накопленного археологического материала и плохо вписывалась в сложившиеся научные интересы исследователя.

Однако внешние факторы не ослабили творческих устремлений А.П. Уманского. В январе 1967 г. он отсылает В.Г. Мирзоеву проспект, два варианта названия и планы диссертации, которые окончательно еще «не вытанцовывались». В апреле 1967 г., вооружившись советами научного руководителя по технической стороне использования архивных фондов [4. Л. 114], А.П. Уманский отправляется в длительную командировку в Москву и Ленинград для работы в Центральном государственном архиве древних актов (ЦГАДА), Ленинградском отделении архива Академии наук, Центральном государственном историческом архиве Ленинграда и библиотеках. Как выяснила Н.А. Гефке, в ЦГАДА он работал в общей сложности два с половиной месяца с 3 апреля до 16 июня. За этот период ему удалось просмотреть описи как минимум десяти фондов и затребовать 169 дел различного объема. Основная часть изученного им материала содержалась в фондах 214 (Сибирский приказ) и 199 (Портфели Миллера) [5].

В ходе поездки, по словам исследователя, обнаружилась «неприятная новость»: над близкой по тематике диссертацией работал аспирант Института истории АН СССР Н.С. Модоров. В связи с этим, чтобы «не оказаться в дураках» и «не повторять зады», барнаульский историк был настроен в ближайшее время опубликовать ряд статей и «нажимать, торопиться изо всех сил, чтобы опередить соперника». Видимо, тяжелые переживания, связанные с перипетиями поступления в аспирантуру, не прошли бесследно, порождая мрачные предчувствия, и в письме к В.Г. Мирзоеву по возвращению из командировки он жалуется на «волю судьбы», которая готовит ему новые испытания [6. Л. 34-34 об.]. Впрочем, с Николаем Семеновичем Модоровым у А.П. Уманского впоследствии установятся вполне деловые, уважительные, хотя и не всегда ровные отношения.

В невероятно короткие сроки уже осенью 1967 г. А.П. Уманский отпечатал на машинке первый вариант диссертации. По его словам, текст получился очень громоздким, и, пытаясь доработать его, он довел себя до нервного истощения и «пал духом» [7. С. 18]. В письме А.П. Окладникову от 19 февраля 1968 г. барнаульский исследователь жалуется ему на свою бо- 
лезнь: «Уже четвертый месяц я не в своей тарелке, точного диагноза поставить не могут, и состояние неизвестности действует просто угнетающе» [8]. В частном письме к другому адресату, отправленному в конце февраля, также фигурирует тема болезни: «В душе тоска неимоверная, какая-то безысходность. Чуть нажал на работу... начались снова апатия, бессонница, боли по всему телу, температура гнилая, в глазах черные точки, ночами в полудреме кошмарные видения и т.п.». С горькой иронией пишет он о том, что «есть перспектива написать “Записки из сумасшедшего дома"» [8]. На физическом состоянии А.П. Уманского сказывалось, видимо, не только крайнее переутомление, связанное с непрерывной интенсивной работой над диссертацией, но и терзавшие его сомнения по поводу соответствия выполненной работы необходимым требованиям и сложностью самостоятельно определить оптимальные пути ее завершения.

В этой ситуации неоценимую помощь и поддержку ему оказал А.П. Окладников. Во время их совместной экспедиционной поездки в Куюс весной 1968 г. он просмотрел рукопись и, по словам А.П. Уманского, вынес вердикт, что она ближе даже не к кандидатской, а к докторской диссертации, и тут же в поле напечатал на нее «весьма положительный» отзыв [7. С. 18-19]. К осени этого же года соискатель переработал первоначальный вариант, который, однако, опять получился в два раза больше нормы. Один из выходов из создавшегося положения он видел в том, чтобы не «ужимать» диссертацию до необходимого объема, а «разрубить» ее на две части, одну из которых защитить в качестве кандидатской, а вторую «оставить до лучших времен». Чтобы принять окончательное решение, он позвонил А.П. Окладникову, который сразу поддержал эту идею [9. С. 19]. Ощутимую конкретную помощь маститый ученый оказывал диссертанту и в дальнейшем. Так, в письме от 19 октября 1969 г. он настойчиво советует «поставить точку на доработке диссертации. Она превосходна». Здесь же он сообщает, что договорился с О.Н. Вилковым о «честном и доброжелательном» оппонировании и даст соответствующее поручение Л.М. Горюшкину по организации защиты [8].

Необходимое содействие диссертанту оказывал и его научный руководитель Владимир Григорьевич Мирзоев. Он не был специалистом по узкой тематике истории этнополитических образований Южной Сибири XVII-XVIII вв., поэтому вряд ли мог обсуждать конкретные проблемы работы. Однако как историограф обладал широкой общеисторической подготовкой, владел методами научной критики источников, был знаком с основными сибиреведческими исследованиями. Между научным руководителем и его подопечным, который был всего на три года младше, сложились вполне рабочие, близкие к партнерским, дружеским взаимоотношения. В одном из писем В.Г. Мирзоеву А.П. Уманский писал: «Никогда не забуду Вашего участия в моей судьбе и судьбе моих научных дел. И если мне когда-нибудь представится слабая возможность воздать добром за добро, я это обязательно сделаю...» [8]. В свою очередь историограф отмечал исследовательскую добросовестность и высокий научный уровень работ соискателя, подчеркивал, что «Ваша профессиональная манера, как историка, весьма мне импонирует» [4. Л. 115].

В декабре 1969 г. А.П. Уманский отослал вариант диссертации на кафедру истории в Кемеровский педагогический институт и предполагаемому оппоненту О.Н. Вилкову в Новосибирск, а уже 5 февраля 1970 г. состоялось ее обсуждение по месту защиты на совместном заседании сектора истории дооктябрьского периода Института истории, филологии и философии CO АН СССР и кафедры истории СССР Новосибирского государственного университета. Диссертация была рекомендована к защите, в выступлениях отмечались ее «высокая научная ценность» и «впечатляющая добротность», подчеркивалось, что соискатель проявил «умение тонкого и разностороннего подхода к источнику и его анализу» [9. Л. 1-5]. Тем не менее в ходе заседания было сделано около 20 конкретных замечаний, которые требовали доработки или уточнения. С учетом этих требований исследователь продолжал интенсивно совершенствовать текст диссертации, включая внесение структурных и содержательных изменений и правок технического характера. В письме к своему научному руководителю В.Г. Мирзоеву от 15 марта этого года А.П. Уманский жалуется: «Пурхаюсь и молю всех богов, чтобы они дали мне сил доделать, так как работоспособность катастрофически падает, и это меня пугает» [8]. К тому же стал возникать вопрос о соотнесении выводов диссертационной работы с концепцией видного исследователя истории и этнографии тюркских народов Саяно-Алтая, заведующего ленинградским отделением Института этнографии АН СССР Л.П. Потапова. В 1969 г. вышла его новая монография «Этнический состав и происхождение алтайцев», которая, по словам соискателя, «многие козыри выбивает... из рук», поскольку содержит ряд идей, развиваемых в диссертационной работе. А.П. Уманский, основательно проработавший к этому времени архивные материалы, нашел в ней «массу чисто фактических ошибок» и теперь находился в раздумье, следует ли на них указывать в кандидатской диссертации [Там же].

Тем не менее к маю 1970 г. окончательный вариант диссертации был подготовлен. Ознакомившись с ним, В.Г. Мирзоев пришел к заключению, что его основные положения «соответствуют уровню нашей науки», и с такой работой «можно смело пускаться в драку» [4. Л. 24]. В начале июня научный руководитель одобрил текст автореферата, отметив, что и в первом чтении он был хорош, а в доработанном виде стал «еще лучше стройнее и лаконичнее» [Там же. Л. 25].

Одновременно с переработкой диссертации А.П. Уманскому пришлось заниматься проблемой пуб- 
ликации результатов своего исследования. С этой целью он зондировал почву в научно-исследовательских институтах и вузах Абакана, Кызыла, Горно-Алтайска, Томска и Новосибирска. В.Г. Мирзоев вел переговоры об издании материалов диссертации отдельной книгой в Кемеровском областном издательстве, однако там требовались не научные монографии, а популярные очерки, доступные для широкого круга читателей [10. Л. 31]. В итоге на первых порах работы А.П. Уманского по телеутской тематике печатались преимущественно в барнаульских изданиях и трудах Новосибирского педагогического института.

Защита диссертации «Телеуты и их тюркоязычные соседи в XVII в. (очерк внешнеполитической истории)» состоялась на Объединенном Ученом совете по гуманитарным наукам Новосибирского государственного университета в октябре 1970 г. Отзывы на диссертацию ведущей организации - Горно-Алтайского научноисследовательского института истории, языка и литературы и официальных оппонентов - 3.Я. Бояршиновой и О.Н. Вилкова были доброжелательными, и защита прошла успешно. Получив стенограмму заседания совета, научный руководитель соискателя писал, что у него создалось впечатление «блестящей защиты», а многие замечания носили формальный характер [4. Л. 26; 11]. В.Г. Мирзоев советовал «немного отдохнуть» и продолжить удачно начатое исследование. В одном из писем А.П. Уманскому он с некоторой долей пафоса восклицал: «Сибирская историография Вам не простит, если Вы не возьметесь за докторскую диссертацию» [4. Л. 26; 8]. Аналогичные мысли высказывал и академик А.П. Окладников: «Что касается продолжения Вашего труда над телеутами, то здесь, как Вы знаете, мои предложения совпадают с тем, что Вам написал В.Г. Мирзоев: делайте дальше, двигайтесь выше! У Вас для этого есть все основания» [8].

В апреле 1971 г. Высшая аттестационная комиссия утвердила А.П. Уманского в искомой научной степени. Эксперт ВАКа, профессор Московского университета, видный исследователь истории и археологии Южной Сибири Л.Р. Кызласов поздравил барнаульского ученого с «весьма ценной работой», отметив «чрезвычайно интересную» тему исследования, постановку и решение проблем социально-экономического и политического строя телеутских княжеств: «Все очень свежо, смело и убедительно. Надеюсь, что Вы опубликуете книгу» [4. С. 58-59 об.].

Воодушевленный удачной защитой, благожелательными отзывами оппонентов, напутствиями научного руководителя и поддержкой директора Института истории, филологии и философии СО АН СССР академика А.П. Окладникова А.П. Уманский решает продолжить работу над телеутской проблематикой, оформив ее в качестве докторской диссертации. Немаловажную роль здесь сыграло то обстоятельство, что значительная часть уже написанного текста не вошла в кандидатскую диссертацию, и при соответствующей доработке могла быть использована на новом этапе научной деятельности.

Одним из условий для достижения поставленной цели было издание монографии, что для провинциального ученого в рамках существовавшей системы организации науки представляло большую сложность. Уже вскоре после защиты кандидатской диссертации в адрес Горно-Алтайского научно-исследовательского института истории, языка и литературы поступило развернутое письмо, подписанное академиком А.П. Окладниковым. В нем институту предлагалось издать кандидатскую диссертацию А.П. Уманского «Телеуты и их соседи в XVII веке (очерки внешнеполитической истории)» в качестве отдельной монографии [12. Л. 2-3]. Однако перенести вопрос в практическую плоскость было крайне сложно. В письме личного характера в ноябре 1971 г. А.П. Уманский с сожалением констатирует: «Дела с изданием книжек идут очень туго, конца-краю не видно... никак не пробьешься сквозь плотные ряды монополистов от науки...» [8]. Один из сюжетов, связанный с приостановкой публикации монографии, раскрывает в своих воспоминаниях горно-алтайский ученый Н.С. Модоров. В самом начале 1971 г. А.П. Уманский написал отрицательную рецензию на его монографию «Русско-алтайские отношения в XVII-XVIII вв.» и не рекомендовал ее к печати (обобщающая монография Н.С. Модорова «Россия и Горный Алтай: политические, социально-экономические и культурные отношения (XVII-XIX вв.)» [13] увидела свет только в 1996 г.; ее рецензентами выступили московские ученые А.А. Преображенский и В.Г. Тюкавкин. Это было уже новое исследование, подготовленное на основе его докторской диссертации). И когда в Горно-Алтайский институт поступила работа барнаульского автора, руководство учреждения приняло «соломоново решение» не отдавать предпочтения ни одной из рукописей и не стало давать им ход [14. C. 167-168].

Тем не менее А.П. Уманский продолжает предпринимать энергичные действия по продвижению своей рукописи в печать. В январе 1973 г. он получает официальное письмо от директора Горно-Алтайского научно-исследовательского института истории, языка и литературы Е.Г. Мултуевой, в котором говорилось о заинтересованности учреждения в издании его кандидатской диссертации и намерении включить монографию в план издательства [10. Л. 34].

В это время устанавливаются контакты между барнаульским исследователем и ленинградским историком и этнографом Л.П. Потаповым. Они обмениваются письмами, поздравительными открытками, изданиями своих трудов. Первоначально тон этих взаимоотношений был самым благожелательным. В первом письме, отправленном в конце февраля, ленинградский ученый пишет: «Мне очень жаль, что Вы так крепко попали в лапы археологии. ...Я сожалею, что Вы забросили исследование письменных памятников XVII в (надо бы и 
XVIII в.), которые никто так не изучал как Вы» [4. Л. 27]. В другом письме, написанном менее чем через десять дней, Л.П. Потапов вновь отдает должное исследовательским заслугам своего сибирского коллеги: «Я почти все Ваши (присланные мне) статьи прочитал и вынес о них самое хорошее впечатление» [6. Л. 46]. В то же время он не скрывает, что по отдельным вопросам можно поспорить, а некоторым критическим замечаниям в его адрес не хватает аргументации.

В свою очередь в ответном письме, отправленном в марте 1973 г., А.П. Уманский пишет: «Ваша посылка и письмо - единственное светлое пятно в моей жизни за последний месяц. ... Такие письма, как Ваши, помогают выкарабкиваться из пропастей, в которые иногда бросает жизнь» [Там же. Л. 44]. С максимальной корректностью он говорит о своих расхождениях с ленинградским историком, хотя и не скрывает, что в его кандидатской диссертации при всем желании не обидеть «первопроходца этой тематики» содержатся критические замечания в его адрес [Там же. Л. 44-45].

В июле 1973 г. в Горно-Алтайске первые произошла личная встреча двух ученых, во время которой ленинградский историк заверил барнаульского коллегу о поддержке его исследовательских начинаний. И действительно, только после рекомендации Л.П. Потапова издательский совет Горно-Алтайского института летом этого же года включил монографию «Телеуты и их соседи в XVII в. (очерк внешнеполитической истории)» в план издания и даже через несколько месяцев выслал автору причитающийся аванс. Работа состояла из двух частей. К публикации в 1975 г. предназначалась первая часть книги объемом 24 печатных листа, которая включала вопросы территориального расположения и внутреннего устройства «Телеутской землицы», а также ее взаимоотношений с азиатскими соседями. Вторую часть книги, посвященную связям телеутов с Русским государством, предполагалось напечатать позже. При этом Л.П. Потапов высказал пожелание написать предисловие к книге и стать ее научным редактором [6. Л. 50-50 об.; 10. Л. 36].

С октября 1974 г. приказом Главного управления высших и средних учебных заведений Министерства просвещения РСФСР А.П. Уманский на один год был переведен на должность старшего научного сотрудника для завершения и защиты диссертации. По истечению срока творческий отпуск был продлен еще на год. «Духовный отец» диссертанта В.Г. Мирзоев прислал необходимый для перевода в старшие научные сотрудники отзыв. В сопроводительном письме он в целом положительно отозвался о возможном участии Л.П. Потапова в редактировании или подготовке предисловия к монографии, но предостерег от соавторства, что могло умалить личный вклад барнаульского автора в написании книги [4. Л. 30].

В течение 1974 - начале 1975 г. А.П. Уманский высылал частями рукопись монографии научному редактору. Л.П. Потапов делал незначительные замечания, рекомендовал подготовить именной и географический указатели, расширить список источников, подработать хронологическую таблицу и карту. К маю 1975 г. автор полностью закончил работу над рукописью и был готов отдать ее литературному редактору, но ждал указаний Л.П. Потапова [6. Л. 54].

Вскоре ленинградский ученый сообщил, что торопиться с подготовкой книги не стоит, поскольку издание перенесено на 1976 г., а летом текущего года он на полтора месяца приедет на Алтай, и в это время «доделаем все без спешки и как следует» [4. Л. 32-33 об., 3535 об., 37-37 об.]. Однако поездка и запланированная встреча не состоялись. В самом начале сентября после возвращения Л.П. Потапова из отпуска и с подвернувшейся оказией А.П. Уманский переправляет подготовленную в основном еще в апреле рукопись в Ленинград. В письме, отправленном из Комарова в конце сентября 1975 г., ленинградский ученый, не называя конкретных сроков, пишет, что «понемногу» продолжает работать над рукописью: «Читаю все подряд, не торопясь, со всем вниманием». На предложение А.П. Уманского приехать в Ленинград, чтобы ускорить доработку монографии, он отвечает, что не видит в этом необходимости. Редактор упоминает также об ухудшении состояния здоровья и снижении работоспособности. При этом он по-прежнему отмечает, что книга «безусловно, хорошая и нужная» [Там же. Л. 39-40].

Такая неопределенность вынудила А.П. Уманского написать «энергичное», по словам Л.П. Потапова, письмо, в котором он высказал претензии в связи с затягиванием редактирования. В ответ в середине декабря ленинградский историк направляет в Барнаул многостраничное послание с многочисленными замечаниями по тексту рукописи. Уже в самом начале письма он нелицеприятно заявляет, что «сия работа мне душу вымотала». Серьезным недостатком книги он считает «излишнюю нетерпимость к инакомыслию», «искусственно созданную» полемику по конкретным «узким» сюжетам, что «бросает тень» на его предшественников, включая и самого Л.П. Потапова.

Через два месяца, к середине февраля 1976 г., автор монографии завершил подготовку пространного ответа на критику редактора. Он кратко благодарит Л.П. Потапова за те замечания, которые считает правильными, но в развернутой форме категорически отвергает большинство критических высказываний. На его взгляд, главная претензия рецензента заключается в том, что в книге присутствует критика трудов Л.П. Потапова [4. Л. 56 об. - 57 об.; 6. Л. 63 об. - 65 об.]. По его словам, вскоре может появиться новая порция замечаний, и «сказочка “про белого бычка" будет продолжена». Завершая своей ответ, барнаульский автор с горечью констатирует: «Жаль, что на Олимпе нашей науки далеко не всегда встречаются “боги”, не просто способные обжигать горшки, но еще и проявлять минимум объективности в оценке степени своего мастерства» [4. Л. 57 об.; 6. Л. 67]. 
Свое письмо с развернутым опровержением претензий А.П. Уманский не решился отправить своему оппоненту, видимо, понимая, что его отдельные эмоциональные высказывания выходят за рамки академической полемики. В то же время его записка являлась необходимым шагом в преодолении затянувшейся тягостной ситуации. Несмотря на серьезные препятствия, он фактически развязал себе руки и стал предпринимать новые энергичные действия по продвижению своих исследований.

Выход из тупиковой ситуации по изданию монографии был найден академиком А.П. Окладниковым. В начале мая 1978 г. он предложил «протолкнуть» рукопись через Институт истории, филологии и философии СО АН СССР, и вскоре ее в срочном порядке затребовали у автора. Пришлось в сжатые сроки дорабатывать текст. «Мучительные раздумья и колебания» автора вызвала необходимость сокращать материал, чтобы уложиться в установленный объем [4. Л. 8484 об.]. К декабрю этого же года была готова корректура книги, а к июлю 1979 г. ее набрали в типографии. Но внезапно возникла новая задержка, которая стала еще одним испытанием для историка. В редакции решили перестраховаться, и гранки отправили в МИД и Институт Дальнего Востока АН СССР на дополнительную экспертизу. Обе организации дали положительные отзывы, но рекомендовали внести некоторые коррективы, в частности, исключить возможность использования книги для обоснования территориальных претензий Китая. Автору пришлось переделать введение и заключение и подработать в соответствующем духе основную часть: «Я уж и сам был не рад, что родился в эпоху советско-китайской конфронтации». Отсюда появление в книге, возможно, удивляющих современных читателей пассажей о необходимости разоблачать клеветнические измышления, происки и фальсификации пекинских гегемонистов и экспансионистов [14. С. 4].

В самом начале 1980 г. десятилетняя эпопея с изданием монографии завершилась, и следовало, по словам автора, «ждать подзатыльников от Л.П. Потапова» [8]. Эмоциональное поздравление в связи с выходом «прекрасной книги» прислал Л.Р. Кызласов. Именитый столичный ученый с пафосом восклицал: «Давно уже не приходилось видеть в сибирской истории исследователя, справедливо и истинно по-ленински оценивающего исторический процесс» [15. Л. 17]. Поздравление с изданием монографии А.П. Уманский получил и от своего научного руководителя по кандидатской диссертации В.Г. Мирзоева. Он писал, что работа производит большое впечатление своей «фундированностью, монбланом источников, умело сведенных в одну логическую схему» [Там же. Л. 2].

Ранее других, 5 февраля 1980 г., сообщение о выходе книги в свет и соответствующие поздравления прислал своему барнаульскому коллеге и младшему товарищу А.П. Окладников. Он просит А.П. Уманского срочно связаться с ученым секретарем совета В.Е. Ла- ричевым, чтобы «двигать» диссертацию: «Пока я жив и в состоянии делать добро хорошим людям» [4. Л. 70]. В январе историк представил монографию вместе со всеми необходимыми документами в совет по защите диссертаций. Еще полгода прошло, пока в начале июля 1981 г. состоялось обсуждение работы в «секторе феодалов» Института истории, филологии и философии. В целом благожелательные отзывы о работе были высказаны О.Н. Вилковым, Н.Н. Покровским, Н.А. Миненко, Л.М. Горюшкиным. По словам Н.А. Миненко, автор подарил читателям исключительно важный труд, книга написана «не равнодушной рукой, а потому и читать ее интересно, и хочется с автором спорить». Л.М. Горюшкин предложил защищать не монографию, а рукопись, в которой можно будет учесть высказанные замечания, тем более что книга больше подвержена критике, и с ней сложнее проходить процедуру защиты [16. Л. 6-11]. Понимая справедливость последнего пожелания, соискатель, тем не менее, предпочел обговорить некоторые дискуссионные моменты в автореферате, поскольку подготовка новой рукописи потребовала бы перепечатку и дополнительную переработку текста, что вызовет новые проволочки, а измученный прежними мытарствами историк «чертовски устал». В итоге монография «Телеуты и русские в XVII-XVIII веках» была рекомендована к защите [9. Л. 14-20].

Таким образом, вся подготовительная работа по представлению монографии была завершена, оставалась лишь небольшая формальность: утверждение темы на Ученом совета Института. Несколько раз по техническим причинам этот вопрос переносили и, наконец, 18 ноября включили в повестку заседания Ученого совета [6. Л. 112-113]. И именно в этот день скончался Алексей Павлович Окладников. Это событие не только потрясло 58-летнего барнаульского ученого в личном отношении, но и в очередной раз поставило под угрозу свершение его научных планов. Совет по защите докторских диссертаций в Институте истории, филологии и философии был закрыт, и его утверждение после смерти А.П. Окладникова затягивалось.

В ходе подготовки к защите пришлось заменить двух из трех намеченных ранее оппонентов. А.П. Бородавкин отказался от предложения, видимо, по причине того, что его научные исследования тематически и хронологически были далеки от телеутской проблематики. К тому же после отрицательной рецензии А.П. Уманского на подготовленную под его руководством книгу по истории Алтайского края у двух историков были натянутые отношения. А.П. Бородавкина в качестве оппонента заменил авторитетный сибирский ученый Н.Н. Покровский. Когда уже в бюллетене ВАК вышло объявление о защите и был отпечатан автореферат, дело опять осложнилось. В связи с затяжной болезнью 3.Я. Бояршинова не смогла дать письменный отзыв и, тем более, приехать на защиту. Выручил омский историк А.Д. Колесников, согласившийся выступить оппонентом. Однако пришлось переоформлять 
бумаги и перепечатывать обложку автореферата. По причине болезни не смог прислать отзыв на автореферат Л.Р. Кызласов. В открытке с извинением он выражал уверенность в успешной защите: «Верю в Вас защитите прекрасно!» [15. Л. 4]. А.П. Уманский остро переживал возникновение этих, в общем-то, технических затруднений. Однако наученный горьким опытом предшествующих неудач, он начинал терять веру в окончательный успех своего дела. В письмах оппонентам Н.Н. Покровскому и Н.А. Миненко и сотруднику ведущей организации А.И. Мартынову он писал, что чувствует ненужность для себя «всей этой затеи» с защитой, что он крайне устал от «возни со злосчастной книжкой»: «Если бы Вы только знали, как все это надоело... Хочется одного - хоть бы скорее любой конец, только конец». При этом он указывал, что обязан довести дело до завершения, поскольку два года находился на должности старшего научного сотрудника, и теперь приходится выслушивать «упреки и нарекания» по поводу того, что надо возвращать долги и восстанавливать кредит доверия, выданный вузу Министерством [6. Л. 119-120, 148]. В ответ соискателем от Н.А. Миненко был получен ободряющий отклик: «Знаю, что защита Ваша пройдет успешно, так как исследование Ваше - серьезное и вполне на уровне докторской диссертации» [4. Л. 81]. В числе причин депрессивного настроения ученого были и преследовавшие его «всевозможные болячки», почти наступивший пенсионный возраст, преждевременная смерть первого научного руководителя В.Г. Мирзоева и, особенно, утрата мощной организационной и человеческой поддержки А.П. Окладникова после ухода его из жизни.

9 июня 1983 г. на заседании специализированного совета при Институте истории, филологии и философии СО АН СССР состоялась защита монографии «Телеуты и русские в XVII-XVIII веках». Все прошло успешно, хотя психологическое состояние А.П. Уманского было тяжелым. И причиной были не замечания оппонентов, которые вполне укладывались в трафарет данной процедуры, а самочувствие барнаульского историка, на котором не смогли не сказаться многочисленные проволочки и препятствия, встретившиеся на его пути к научной вершине. На этом хотелось бы поставить окончательную победную точку в описании сложного тернистого пути барнаульского историка к научному Олимпу. В октябре 1983 г. был торжественно отпразднован 60-летний юбилей со дня рождения ученого, в ходе которого было высказано немало заслуженных лестных слов по поводу научных достижений юбиляра, его творческих дарований и замечательных человеческих качеств. Сам Алексей Павлович выглядел приободренным, пессимистические настроения, казалось, ушли в прошлое. Но судьба уготовила ему еще одно серьезное испытание. Произошло то, чего он сам опасался и неоднократно говорил о такой возможности, но в глубине души, конечно, надеялся избежать этой неприятности. В высшую аттестационную комиссию поступила отрицательная рецензия на его монографию. Ее копия была переслана соискателю, и, видимо, потребовались крайнее напряжение и изнуряющая внутренняя мобилизация, чтобы к середине мая 1984 г. подготовить 20-страничные ответы на замечания.

Некоторые претензии анонимного рецензента касались не столько научной стороны книги, сколько ставили неприглядную цель показать идеологическую незрелость работы, будто бы отвечающей проискам буржуазных фальсификаторов, которые настаивали на агрессивности русского народа, захвате чужих земель и пр. Это обвинение было очень неприятным и даже опасным для любого историка той эпохи, поскольку критика «буржуазных фальсификаторов» считалась одной из приоритетных задач советской историографии [16. Л. 32].

Серьезное обвинение в научной недобросовестности было выдвинуто рецензентом только на основании одного случая, когда автор не подтвердил свою мысль ссылкой на источники. Отвергая это несправедливое и обидное замечание, соискатель не мог удержаться от эмоциональной реплики: «Обвинение в научной недобросовестности адресовано рецензентом человеку, в книге которого сделано свыше 1000 ссылок на более чем 600 архивных дел и 350 названий специальной литературы, на изучение которых им затрачено почти 30 лет жизни» [Там же. Л. 40].

Завершая объяснительную записку, А.П. Уманский пишет, что у него есть все основания считать, что рецензия носит поверхностный, предвзятый и тенденциозный характер: «Я далек от мысли считать свою монографию свободной от ошибок и недостатков. ...Но с замечаниями и обвинениями рецензента по книге я не могу согласиться» [Там же. Л. 42]. Здесь необходимо отметить, что при всей сложности и, нередко, неоднозначности позиций сторон в научных дискуссиях, в данном случае надо признать правоту барнаульского историка. Рецензент действительно ставил перед собой весьма неблаговидную цель выявить только негативные моменты и подвергнуть книгу полному разгрому. Он редко спорит по существу, а чаще выдвигает самые общие обвинения, стремясь уличить автора в недостаточной источниковедческой и историографической подготовке, ошибочной трактовке глобального процесса колонизации и даже идеологической незрелости. При этом отстаиваемые рецензентом исторические оценки в большей степени базировались не на анализе конкретного исторического материала, а на историографических стереотипах и политической конъюнктуpe. Почти все замечания сделаны по введению, заключению и первой главе первой части монографии. Основное содержание книги осталось вне зоны внимания рецензента, поэтому мнение А.П. Уманского о поверхностном и тенденциозном характере отзыва можно считать вполне обоснованным.

Вместе с письменными ответами на претензии в адpec монографии историк был вызван на заседание экс- 
пертной комиссии ВАКа, где давал необходимые пояснения по поводу своей работы. К счастью, членами комиссии оказались разумные люди достаточной квалификации, которые смогли увидеть надуманность многих обвинений и оценить подлинную научную значимость представленной к защите работы. В итоге последовало долгожданное действительно выстраданное присвоение ученому искомой степени доктора исторических наук. Почти 15 лет жизни ушло на то, чтобы преодолеть все трудности с изданием монографии и защитой диссертационного сочинения. На первый взгляд, 15 лет для написания и защиты докторской диссертации - это вполне приемлемый срок, который необходим для подготовки фундаментальной работы. Однако парадоксальность и даже трагизм ситуации с научным продвижением А.П. Уманского заключаются в том, что основной материал по теме им был собран и значительная часть работы в черновом варианте написана еще в конце 1960-х гг. А огромная часть времени и сил впоследствии были потрачены на преодоление административных барьеров, бюрократических препонов, решение различных организационных вопросов. При этом надо отдать должное упорству и целеустремленности ученого, который после каждой неудачи сумел находить в себе силы, чтобы вновь и вновь двигаться в избранном направлении.

Что касается публикации той части его работы, которая была защищена в качестве кандидатской диссертации, а затем в переработанном виде много лет пролежала в Горно-Алтайске, то А.П. Уманский не оставлял надежды на ее выход в свет. С этой целью он в конце 1980-х гг. зондировал почву в ряде издательств. Однако ситуация в стране изменилась, старая система прохождения рукописей рухнула, а новая еще не сформировалась. В этих условиях отпала необходимость согласования положений работы с научным редактором, на первый план вышли финансовые вопросы, а в начале 1990-х гг. еще и поиск типографии и ресурсов бумаги. Всем этим пришлось заниматься автору, чтобы, наконец, обнародовать результаты своего труда. В результате была найдена относительно дешевая и незагруженная типография в селе Топчиха Алтайского края. Ученик и коллега Алексея Павловича А.А. Прохожев, используя старые партийные связи, сумел приобрести необходимый объем бумаги. В октябре 1993 г. с типографией был подписан договор, по которому она обязывалась до конца года напечатать тираж. Однако еще более года шли согласования сторон, резко росли цены, появлялись внеочередные заказы для типографии, и только в конце февраля 1995 г. Барнаульский педуниверситет оплатил счет на сумму 4 млн 551 тыс. руб. Прошло еще более полутора лет ожидания, и лишь в конце 1996 г., спустя чуть ли ни четверть века после начала злоключений с ее изданием, она появилась в свет $[17,18]$. Однако автор не случайно сетовал, что «тысячу раз пожалел, что... решился печатать книгу» в Топчихе. Качество полиграфии оказалось отвратительным, заглавие работы на странице с выходными данными было перепутано, две страницы текста во второй части, одна страница в хронологической таблице и условные обозначения под картой-схемой были пропущены, и их вместе с названием пришлось заново отпечатывать и вклеивать вручную. Кроме того, книга публиковалась в двух частях по 500 экземпляров каждая. Типография же умудрилась первую часть издать в количестве 700 экземпляров, а вторую - 300! [6. Л. 138-139]. Поистине подумаешь, что какой-то злой рок преследовал эту работу, написанную ценой невероятных усилий еще в конце 1960-х гг.

Таким образом, ученый сумел издать почти все, что подготовил по политической истории «Телеутской землицы». Из задуманного не удалось опубликовать специальную работу по дальнейшей судьбе «выезжих телеутов», однако отдельные материалы по этой тематике были представлены в ряде его статей. Современные авторы, занимающиеся историей народов юга Западной Сибири, апеллируют к материалам А.П. Уманского при описании событийной стороны бурных событий русской колонизации, характеристике существовавших здесь этнополитических образований, изучении межгосударственных и межэтнических контактов. В целом комплексе сложных дискуссионных вопросов истории региона в XVII-XVIII вв. суждения и выводы ученого по-прежнему имеют существенный вес. В их числе заключение о военно-политических целях русско-телеутских договоров, установление времени и характера зависимости «Телеутской землицы» от западномонгольких правителей, определение роли «выезжих белых калмыков» в формировании кузнецких и томских телеутов, критика как теории «завоевания», так и концепции бесконфликтного включения народов Южной Сибири в состав Российского государства $[12$. С. $52 ; 19$. С. $96 ; 20$. С. $64,124,126 ; 21$. С. 176 ; 22. C. 8,$196 ; 23$. C. $43 ; 24$. C. $3,22-23$; 25 . C. $12-13$, $20-$ $21,24,33]$. Основанные на глубоком анализе обширного архивного материала труды А.П. Уманского получили высокую оценку в историческом сообществе, и по настоящее время он является признанным в научном мире специалистом по телеутской проблематике.

\section{ЛИТЕРАТУРА}

1. Демин М.А. Археологические исследования А.П. Уманского на Алтае (1956-1963 гг.) // Известия Алтайского государственного университета. Серия: исторические науки и археология. 2016. № 2 (90). С. 200-205.

2. Демин М.А. Историко-краеведческие исследования А.П. Уманского во второй половине 1950-х - начале 1960-х гг. // Гуманитарные науки в Сибири. 2016. № 1. С. 96-101.

3. Демин М.А. Ученый и бюрократия (к истории нереализованного варианта научной биографии А.П. Уманского) // Вестник Томского государственного университета. История. 2018. № 51. С. 143-148.

4. Государственный архив Алтайского края (ГААК). Ф. Р-1820. Оп. 1. Д. 150.

5. Гефке Н.А. Алексей Павлович Уманский как исследователь документов Российского государственного архива древних актов // Вопросы археологии и истории юга Западной Сибири. Барнаул: АлтГПА, 2013. С. 76-89. 
6. ГААК. Ф. Р-1820. ОП. 1. Д. 149.

7. Уманский А.П. Великий труженик науки // Вопросы археологии и истории юга Западной Сибири. Барнаул : АлтГПА, 2013. С. 13-28.

8. ГААК. Ф. Р-1820. Неописанные материалы.

9. ГААК. Ф. Р-1820. Оп. 1. Д. 160.

10. ГААК. Ф. Р-1820. Оп. 1. Д. 155

11. Уманский А.П. Телеуты и русские в XVII-XVIII веках. Новосибирск : Наука, 1980. 296 с.

12. ГААК. Ф. Р-1820. ОП. 1. Д. 189.

13. Модоров Н.С. Россия и Горный Алтай: политические, социально-экономические и культурные отношения (XVII-XIX вв.) / Ком. образования и науки Респ. Алтай, Науч.-метод. центр, Горно-Алт. гос. ун-т. Горно-Алтайск : Изд-во Горно-Алт. ун-та, 1996. 396 с.

14. Модоров Н.С. Слово о коллеге // Вопросы археологии и истории Сибири: памяти профессора А.П. Уманского : сб. ст. / редкол.: Т.И. Баталова, М.А. Демин, Т.К. Щеглова. Барнаул : БГПУ, 2008. С. 165-169.

15. ГААК. Ф. Р-1820. Оп. 1. Д. 151.

16. ГААК. Ф. Р-1820. Оп. 1. Д. 128.

17. Уманский А.П. Телеуты и их соседи в XVII - первой четверти XVIII века / Барнаульский государственный педагогический университет, Лаборатория исторического краеведения ; отв. ред. О.Н. Вилков : в 2 ч. Барнаул : Изд-во Барнаульского педагогического госуниверситета, 1995. Ч. I. $171 \mathrm{c.}$

18. Уманский А.П. Телеуты и их соседи в XVII - первой четверти XVIII века / Барнаульский государственный педагогический университет, Лаборатория исторического краеведения ; отв. ред. О.Н. Вилков : в 2 ч. Барнаул : Изд-во Барнаульского педагогического госуниверситета, 1995. Ч. II. $221 \mathrm{c}$.

19. Алтайцы: Этническая история. Традиционная культура. Современное состояние / Н.В. Екеев (отв. ред.), Н.М. Екеева, Э.В. Енчинов; НИИ алтаистики им. С.С. Суразакова. Горно-Алтайск : Горно-Алт. тип., 2014. 464 с.

20. Шерстова Л.И. Этнополитическая история тюрков Южной Сибири в XVII-XIX веках / науч. ред. Ю.В. Куперт. Томск : ТПУ, 1999.434 с.

21. Функ Д.А. Телеуты. Общие сведения // Тюркские народы Сибири / отв. ред. Д.А. Функ, Н.А. Томилов. М. : Наука, 2006. С. 171-176.

22. Самаев Г.П. Горный Алтай в XVII - середине XIX в.: проблемы политической истории и присоединения к России. Горно-Алтайск : Алт. кн. изд-во, 1991. 256 с.

23. Екеев Н.В. Проблемы этнической истории алтайцев (исследование и материалы). Горно-Алтайск : Горно-Алт. тип., 2011. 232 с.

24. Тенгереков И.С. Теленгеты. Историко-этнографический очерк. Горно-Алтайск : Юч-Сюмер-Белуха, 2001.79 с.

25. Кимеев В.М. Исторические судьбы телеутов. Кемерово : Изд-во Кемеров. гос. ун-та, 2017. 142 с.

Dyomin Mikhail A. Altai State Pedagogical University (Barnaul, Russia). E-mail: mademin52@mail.ru

\section{A THORNY PATH TO SCIENCE}

Keywords: Umansky; history; Teleuts; review; monograph; thesis.

The article is based on unpublished archival sources and reveals the vicissitudes associated with the publication of monographs and the defense of dissertations by the well-known Siberian historian and archaeologist Alexei Pavlovich Umansky. His contacts with the leading Russian humanitarians - Siberian experts: A.P. Okladnikov, L.P. Potapov, V.G. Mirzoev, L.R. Kyzlasov, N.A. Minenko, which are of interest for the study of scientific communication as one of the basic mechanisms of the functioning of the scientific community, are analyzed. The publication touches upon issues related to the daily scientific life of the researcher ("historiographical way of life"), as well as psychological problems caused by the need to overcome numerous difficulties on the way of scientific advancement. One of the conditions for the defense of a doctoral dissertation was the publication of the monograph, which for a provincial scientist within the existing system of organization of science was of great complexity. A tangible concrete help and substantial support to the competitor was provided by Academician A.P. Okladnikov.

The article for the first time examines the polemics between L.P. Potapov and A.P. Umansky and analyzes an anonymous review of his monograph, which was received by the Higher Attestation Commission. A conclusion about the superficial and tendentious nature of the review was made, largely based on historiographical stereotypes, often paying tribute to the political conjuncture.

Almost 15 years of life A.P. Umansky spent on overcoming all difficulties with the publication of the monograph and defending the dissertation work. At the same time, the paradox and even the tragedy of the situation with his scientific advancement lies in the fact that the main material on the topic was collected, and much of the work in the draft version was written in an earlier period, even before the beginning of the preparation of the doctoral dissertation. A huge part of the time and energy was subsequently spent on overcoming bureaucratic obstacles and solving various organizational matters. Thus it is necessary to pay tribute to persistence and purposefulness of the scientist, who after each failure managed to find the strength and to move again in the chosen direction.

Modern authors, dealing with the history of the peoples of the south of Western Siberia, appeal to the materials of A.P. Umansky in describing the eventual side of Russian colonization, describing the ethnopolitical formations that existed here, studying interstate and interethnic contacts. Based on a thorough analysis of the vast archival material, the judgments and conclusions of the researcher still have a significant weight, and he is a recognized expert in the scientific world on teleut problems.

\section{REFERENCES}

1. Demin, M.A. (2016a) A.P. Umansky's Archeological Research in Altai (1956-1963). Izvestiya Altayskogo gosudarstvennogo universiteta. Seriya: istoricheskie nauki i arkheologiya - Izvestiya of Altai StateUniversity Journal. 2(90). pp. 200-205. (In Russian). DOI: 10.14258/izvasu(2016)2-36

2. Demin, M.A. (2016b) Istoriko-kraevedcheskie issledovaniya A.P. Umanskogo vo vtoroy polovine 1950-kh - nachale 1960-kh gg. [Local history studies of A.P. Umansky in the second half of the 1950s - early 1960s]. Gumanitarnye nauki v Sibiri. 1. pp. 96-101.

3. Demin, M.A. (2018) The scientist and the bureaucracy (to the history of the unrealized version of scientific biography of A. P. Umansky). Vestnik Tomskogo gosudarstvennogo universiteta. Istoriya - Tomsk State University Journal of History. 51. pp. 143-148. (In Russian). DOI: $10.17223 / 19988613 / 51 / 20$

4. The State Archive of the Altai Territory (GAAK). Fund R-1820. List 1. File 150.

5. Gefke, N.A. (2013) Aleksey Pavlovich Umanskiy kak issledovatel' dokumentov Rossiyskogo gosudarstvennogo arkhiva drevnikh aktov [Alexey Pavlovich Umansky as a researcher of documents of the Russian State Archive of Ancient Acts]. In: Demin, M.A. (ed.) Voprosy arkheologii $i$ istorii yuga Zapadnoy Sibiri [Problems of Archeology and History of the South of Western Siberia]. Barnaul: Altai State Pedagogical Academy. pp. 76-89.

6. The State Archive of the Altai Territory (GAAK). Fund R-1820. List 1. File 149.

7. Umanskiy, A.P. (2013) Velikiy truzhenik nauki [The great researcher]. In: Demin, M.A. (ed.) Voprosy arkheologii $i$ istorii yuga Zapadnoy Sibiri [Problems of Archeology and History of the South of Western Siberia]. Barnaul: Altai State Pedagogical Academy. pp. 13-28.

8. The State Archive of the Altai Territory (GAAK). Fund R-1820.

9. The State Archive of the Altai Territory (GAAK). Fund R-1820. 
10. The State Archive of the Altai Territory (GAAK). Fund R-1820.

11. The State Archive of the Altai Territory (GAAK). Fund R-1820.

12. The State Archive of the Altai Territory (GAAK). Fund R-1820.

13. The State Archive of the Altai Territory (GAAK). Fund R-1820. List 1. File 160.

14. The State Archive of the Altai Territory (GAAK). Fund R-1820. List 1. File 155.

15. The State Archive of the Altai Territory (GAAK). Fund R-1820.

16. The State Archive of the Altai Territory (GAAK). Fund R-1820. List 1. File 189.

17. The State Archive of the Altai Territory (GAAK). Fund R-1820.

18. Modorov, N.S. (1996) Rossiya i Gornyy Altay: politicheskie, sotsial'no-ekonomicheskie i kul'turnye otnosheniya (XVII-XIX vv.) [Russia and Gorny Altai: political, socio-economic and cultural relations (the 17th - 19th centuries)]. Gorno-Altaysk: Gorno-Altaysk State University.

19. Modorov, N.S. (2008) Slovo o kollege [A word about a colleague]. In: Batalova, T.I., Demin, M.A. \& Shcheglova, T.K. (eds) Voprosy arkheologii $i$ istorii Sibiri [Problems of Archeology and History of Siberia]. Barnaul: Barnaul State Pedagogical University. pp. $165-169$.

20. Umanskiy, A.P. (1980) Teleuty i russkie v XVII-XVIII vekakh [Teleuts and Russians in the 17th - 18th centuries]. Novosibirsk: Nauka.

21. The State Archive of the Altai Territory (GAAK). Fund R-1820.

22. The State Archive of the Altai Territory (GAAK). Fund R-1820. List 1. File 151

23. The State Archive of the Altai Territory (GAAK). Fund R-1820. List 1. File 128.

24. Umanskiy, A.P. (1995) Teleuty i ikh sosedi v XVII - pervoy chetverti XVIII veka [Teleuts and their neighbours in the 17th century - the first quarter of the 18th centuries]. In: Vilkov, O.N. (ed.) Barnaul'skiy gosudarstvennyy pedagogicheskiy universitet, Laboratoriya istoricheskogo kraevedeniya [Barnaul State Pedagogical University, Laboratory of Historical Local History]. Vol. 1. Barnaul: Barnaul State Pedagogical University.

25. Umanskiy, A.P. (1995) Teleuty i ikh sosedi v XVII - pervoy chetverti XVIII veka [Teleuts and their neighbours in the 17th century - the first quarter of the 18th centuries]. In: Vilkov, O.N. (ed.) Barnaul'skiy gosudarstvennyy pedagogicheskiy universitet, Laboratoriya istoricheskogo kraevedeniya [Barnaul State Pedagogical University, Laboratory of Historical Local History]. Vol. 2. Barnaul: Barnaul State Pedagogical University.

26. Ekeev, N.V. (ed.) Altaytsy: Etnicheskaya istoriya. Traditsionnaya kul'tura. Sovremennoe sostoyanie [Altaians: Ethnic History. Traditional culture. The current state]. Gorno-Altaysk: Gorno-Altaiskaya tipografiya.

27. Sherstova, L.I. (1999) Etnopoliticheskaya istoriya tyurkov Yuzhnoy Sibiri v XVII-XIX vekakh [Ethnopolitical history of the Türks of Southern Siberia in the 17th -19 th centuries]. Tomsk: Tomsk Polytechnic University.

28. Funk, D.A. (2006) Teleuty. Obshchie svedeniya [Teleuts. General information]. In: Funk, D.A. \& Tomilov, N.A. (eds) Tyurkskie narody Sibiri [Turkic peoples of Siberia]. Moscow: Nauka. pp. 171-176.

29. Samaev, G.P. (1991) Gornyy Altay v XVII - seredine XIX v.: problemy politicheskoy istorii $i$ prisoedineniya $k$ Rossii $[$ Gorny Altai in the 17 th - mid 19th century: problems of political history and accession to Russia]. Gorno-Altaysk: Altaiskoe knizhnoe izdatelstvo.

30. Ekeev, N.V. (2011) Problemy etnicheskoy istorii altaytsev (issledovanie i materialy) [Problems of Altai ethnic history (research and materials)]. Gorno-Altaysk: Gorno-Altaiskaya tipografiya.

31. Tengerekov, I.S. (2001) Telengety. Istoriko-etnograficheskiy ocherk [Telengety. A Historical and Ethnographic Essay]. Gorno-Altaysk: YuchSyumer-Belukha.

32. Kimeev, V.M. (2017) Istoricheskie sud'by teleutov [The historical fate of the Teleuts]. Kemerovo: Kemerovo State University. 